\title{
Fellow of American College of Physicians
}

National Cancer Institute

\section{Source}

National Cancer Institute. Fellow of American College of Physicians. NCI Thesaurus. Code C39401.

Fellow of American College of Physicians is a member of society of internal medicine practitioners. Reflects education and training, professional qualifications and competence, and ethical conduct consistent with standards established by the College. 